\title{
積分方程式法による弾塑性問題の解析 \\ APPLICATION OF INTEGRAL EQUATION METHOD TO \\ ELASTOPLASTIC BOUNDARY VALUE PROBLEMS
}

\author{
小 林 昭 一*・西 村 直 志** \\ By Shoichi KOBAYASHI and Naoshi NISHIMURA
}

\section{1. 序}

今日, 積分方程式法は線形問題, 特に静弾性学の境界 值問題の解法としてしばしば用いられている. 一方, 弾 塑性問題などの非線形問題への応用可能性については比 較的初期の段階から指摘されているにもかかわらず，そ の後の進展をみていない現状である. その原因として は，(1) 必ずしも数值計算に適しているとはいえない積 分表示が使われていたこと, (2) 研究者の間に積分方程 式の特異性や, 塑性論そのものへの認識不足があったこ と，などが指摘されよう。たとえば弾性論の Green 公 式を弾塑性へ拡張した Swedlow-Cruse の式(1),3) は, 応 力境界値問題へ適用した場合，本論文で述べる一重層ポ テンシャル法に比較して積分計算量が多くなる．また応 力関数を用いる方法 ${ }^{2}{ }^{3}$, も, 変位が求めにくい5え, 3 次 元への拡張ができないこと，用いる近似関数を高次のも

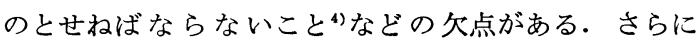
Swedlow-Cruse の式を直接平面問題に適用してきたこ れまでの研究には誤りがあることが最近ようやく注意さ れている5)（もっともこの文献 5）には，微積分の順序 交換に関する重大な誤りがある. 多少ともポテンシャル 論の知識を有する者にとって，このことは文献 6) の指 摘を待つまでもないであろう).このように，積分方程 式法による弾塑性問題の解析に関する研究は, 事実上こ の手法の良否をうんぬんする段階には達していないとみ てよい.

一方, 著者らは近年弾性学の応力境界值問題の解法と しての一重層ポテンシャル法の有利さを指摘してきた. 一重層ポテンシャル法の場合, Green 公式と違って二重 層ポテンシャルを含まず, 関数近似および積分計算量の 面で有利である ${ }^{4)}$. この手法を弾塑性問題へ応用すれば,

* 正会員 工博 京都大学教授 工学部土木工学科

** 正会員 工修 京都大学助手 工学部土木工学科
従来の積分方程式による解法より有効な手法となり得る であろう．さらに，積分方程式法本来の利点である未知 数の個数の減少, および特異性の表現の容易さを生かす ことにより，FEM，FDM などの従来の手法以上の結果 を期待することも可能であろう．たとえば，弹塑性境界 は一重層ないしは微分した物体ポテンシャルの密度の不 連続面として表現できることを以下に示すが，特異面と しての弾塑性境界を他の方法で表現することは容易では ない. 本論文はそのような観点から新しい積分方程式法 による弾塑性問題の定式化の可能性を検討したものであ る. まず一重層ポテンシャル法を用いた弾塑性問題の解 析法を定式化する．次に二重層ポテンシャルの利点を生 かし得るのはクラックの問題であることに注目し, 二重 層ポテンシャル法によるクラックの弹塑性解析法につい て述べる．最後にこれらの手法の適用性を検討する意味 で,ごく簡単な数值例を若干示す.

\section{2. 準備}

以下で必要となる結果を参照の便宜のために掲げる.

\section{（1）塑性学からの準備}

a) 構成仮定

本論文で扱ら増分理論による微小変形弾塑性構成式は 次の形に表示され得るものである。なお，簡単のために 単一降伏条件の場合に限定する.

(i) 降伏関数 :

$$
f(\boldsymbol{\tau}, \boldsymbol{\xi})
$$

ここに $\tau$ は応力, $\boldsymbol{\varepsilon}$ は内部パラメーター(の組), たと えば塑性ひずみ $\boldsymbol{\epsilon}^{p}$, 塑性仕事 $\int \tau: d \epsilon^{p}\left(:\right.$ は $\int \tau: d \epsilon^{p}$ $=\int \tau_{i j} d \epsilon^{p}{ }_{i j}$ 等を表す) など (の組) である. $f(\boldsymbol{\tau}, \boldsymbol{\xi})$ $\leqslant 0$ なる $(\boldsymbol{\tau}, \boldsymbol{\xi})$ のみ実現し得る. 完全弾塑性体では $\boldsymbol{\xi}$ は現れない。 
(ii) 流れ則

連合流れ則を仮定する。すなわち，

$$
d \epsilon^{p}=\frac{\partial f}{\partial \tau} d \lambda
$$

ここに $d \lambda$ は,

$$
\left\{\begin{array}{l}
d \lambda=0 \frac{\partial f}{\partial \boldsymbol{\tau}}: \boldsymbol{d} \boldsymbol{\tau}<0, f=0 \text { または } f<0 \text { のとき } \\
d \lambda>0 \frac{\partial f}{\partial \boldsymbol{\tau}}: \boldsymbol{d} \boldsymbol{\tau}>0, f=0 \text { のとき }
\end{array}\right.
$$

となるパラメーターである. $\frac{\partial f}{\partial \tau}: d \tau=0, f=0$ のとき， 硬化があれば $d \lambda=0$, 完全弾塑性体では $d \lambda>0$ である.

(iii) 移行 (発展) 式

$$
d \boldsymbol{\xi}=\boldsymbol{\theta}(\tau, \boldsymbol{\xi}): \boldsymbol{d} \boldsymbol{\epsilon}^{p}
$$

を仮定する．塑性ひずみ（この場合 $\theta_{i j k l}=\delta_{i k} \delta_{j l}$ ），塑 性仕事（この場合 $\boldsymbol{\theta}=\boldsymbol{\tau}$ ）など（の組）はこの条件を満 たす。

以上の仮定のもとに，

$$
\boldsymbol{d \epsilon} \boldsymbol{\epsilon}^{p}=\frac{\partial f}{\partial \tau}(\boldsymbol{D}: \boldsymbol{d} \boldsymbol{\epsilon})
$$

となる. ここに $\boldsymbol{D}$ は次の形の増分量によらない 2 階の テンソル

$$
\boldsymbol{D}=\frac{\frac{\partial f}{\partial \boldsymbol{\tau}}: \boldsymbol{C}}{\frac{\partial f}{\partial \boldsymbol{\tau}}: \boldsymbol{C}: \frac{\partial f}{\partial \boldsymbol{\tau}}-\frac{\partial f}{\partial \boldsymbol{\xi}} * \boldsymbol{\theta}: \frac{\partial f}{\partial \boldsymbol{\tau}}}
$$

であり, de はひずみ増分である. また式（5）で $\boldsymbol{C}$ は 弾性常数テンソル（一応等方性を仮定して $\boldsymbol{C}: \boldsymbol{\epsilon}=\lambda 1 \mathrm{tr}$ $\boldsymbol{\epsilon}+2 \mu \epsilon$ とするが，この仮定は必ずしも必要ではない)， * は適当な積である (たとえば, 文献 8） p. 67 参照). 完全弾塑性体では $\frac{\partial f}{\partial \boldsymbol{\xi}} * \boldsymbol{\theta}: \frac{\partial f}{\partial \tau}=0$ である.

b) つり合い式

3 次元の場合，および平面ひずみ状態でのつり合い式 は，

$$
\begin{aligned}
& \Delta^{*} \boldsymbol{d} \boldsymbol{u}-\left(\boldsymbol{C}: \boldsymbol{d} \epsilon^{p}\right) \cdot \boldsymbol{\nabla}=\mathbf{0} \text { in } D^{e} \cup D^{p} \ldots \ldots \ldots \\
& \boldsymbol{n}^{e p} \boldsymbol{T} \boldsymbol{d} \boldsymbol{u}^{-}=\boldsymbol{T} \boldsymbol{d} \boldsymbol{d} \boldsymbol{u}^{+}-\left(\boldsymbol{C}: \boldsymbol{d} \epsilon^{p^{+}}\right) \cdot \boldsymbol{n}^{e p} \text { on } \partial D^{e p}
\end{aligned}
$$

となる.ここに $D^{e}\left(D^{p}\right)$ は弾 (塑) 性域, $\partial D^{e p}$ は弾 塑性境界を表し， $\boldsymbol{n}^{e p}$ は塑性域から弾性域を向く方向を 正とした， $\partial D^{e p}$ に立てた単位法線べクトルである。 はグラディエントである. $\Delta^{*}$ は Navier 作用素

$$
\boldsymbol{\Delta}^{*}=\mu \Delta+(\lambda+\mu) \boldsymbol{\nabla} \boldsymbol{\nabla} \cdot(\Delta: \text { ラプラシアン })
$$

$\stackrel{n}{\boldsymbol{T}}$ は弾性表面力作用素

$$
\stackrel{\boldsymbol{n}}{\boldsymbol{T}}=\lambda \boldsymbol{n} \boldsymbol{\nabla} \cdot+\mu\left(\frac{\partial}{\partial \boldsymbol{n}}+\boldsymbol{\nabla} \boldsymbol{n} \cdot\right)
$$

である．諸量の肩に付けた+，一は，本論文では，後述 の一重層ポテンシャルの符号に合わせてそれぞれ内，外 部極限を表すことにする. 式 (7) での内 (外) 部極限は
塑 (弾) 性側からの極限となる. $\boldsymbol{d} \boldsymbol{\epsilon}^{p^{+}}$は一般に0にはな らない, なお, 平面ひずみでは， $\boldsymbol{C}: \boldsymbol{d} \boldsymbol{\epsilon}^{p}$ における $\mathrm{tr}$ $d \epsilon^{p}$ は $d \epsilon^{p_{11}}+d \epsilon^{p_{22}}+d \epsilon^{p_{33}}$ と解すべきである. 平面応 力状態を考える場合は，上の諸式で $\lambda$ を $2 \mu \lambda /(\lambda+2 \mu)$ で直き換えるとよい.この場合， $\boldsymbol{C}: \boldsymbol{d} \boldsymbol{\epsilon}^{p}$ における $\operatorname{tr}$ $\boldsymbol{d \epsilon}^{p}$ は $d \epsilon^{p}{ }_{11}+d \epsilon^{p}{ }_{22}$ と解すべきであり, 体積塑性ひず み=0 と仮定しても一般には $\operatorname{tr} \boldsymbol{d} \boldsymbol{\epsilon}^{p}=-d \epsilon^{p_{3}} \neq 0$ であ ることに注意しなければならない.

\section{（2）ポテンシャル論からの準備7)}

$\boldsymbol{\Gamma}(\boldsymbol{x}, \boldsymbol{y})$ を無限弾性体の Green テンソルとする.

(i) 一重層ポテンシャル

$\boldsymbol{V}(\boldsymbol{x})=\int_{\partial D} \boldsymbol{\Gamma}(\boldsymbol{x}, \boldsymbol{y}) \cdot \boldsymbol{\varphi}(\boldsymbol{y}) d S_{\boldsymbol{y}}$ は $\partial D$ を超えて連続 であり, $\partial D$ への内（外）部極限は，

$$
\begin{aligned}
& \stackrel{n}{\boldsymbol{T}} \boldsymbol{V}^{ \pm}(\boldsymbol{x})= \pm \frac{\varphi(\boldsymbol{x})}{2}+\int_{\partial D} \stackrel{n}{\boldsymbol{T}} \boldsymbol{\Gamma}(\boldsymbol{x}, \boldsymbol{y}) \cdot \boldsymbol{\varphi}(\boldsymbol{y}) d S_{y}, \\
& \boldsymbol{x} \in \partial D
\end{aligned}
$$

を満たす. $\boldsymbol{n}$ は $\boldsymbol{x}$ における $\partial D$ の外向き単位法線べク トルであり， $\varphi$ は一重層密度とよばれるベクトル值関数 である. また $\stackrel{n}{\boldsymbol{T}}$ は $\boldsymbol{\Gamma}$ に前から作用し, 微分は $\boldsymbol{x}$ に関 してとる. $d S_{y}$ は変数 $\boldsymbol{y}$ に関する積分を意味する.

(ii) 二重層ポテンシャル

$$
\begin{aligned}
& \boldsymbol{W}(\boldsymbol{x})=\int_{\partial D} \Gamma_{\mathrm{I}}(\boldsymbol{x}, \boldsymbol{y}) \cdot \boldsymbol{\phi}(\boldsymbol{y}) d S_{y}, \Gamma_{\mathrm{I}}(\boldsymbol{x}, \boldsymbol{y}) \\
& =\Gamma(x, y) \stackrel{\check{n}}{T} \text { は, } \\
& \boldsymbol{W}^{ \pm}(\boldsymbol{x})=\mp \frac{\boldsymbol{\phi}(\boldsymbol{x})}{2}+\int_{\partial D} \Gamma_{\mathrm{I}}(\boldsymbol{x}, \boldsymbol{y}) \cdot \boldsymbol{\psi}(\boldsymbol{y}) d S_{y}, \\
& x \in \partial D
\end{aligned}
$$

を満たす.ここに $\boldsymbol{\phi}$ は二重層密度とよばれるべクトル

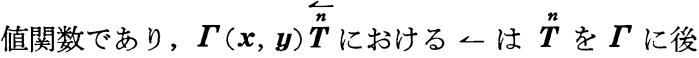
から作用させ, 微分は $\boldsymbol{y}$ に関してとることを意味する. $\boldsymbol{n}$ は点 $\boldsymbol{y}$ でのものである.

(iii) 物体ポテンシャル $\boldsymbol{X}(\boldsymbol{x})=\int_{D} \boldsymbol{\Gamma}(\boldsymbol{x}, \boldsymbol{y}) \cdot \boldsymbol{\chi}(\boldsymbol{y}) d V_{\boldsymbol{y}}$ は, $D$ において Poisson の公式

$$
\boldsymbol{A}^{*} \boldsymbol{X}(\boldsymbol{x})=-\boldsymbol{\chi}(\boldsymbol{x}) \quad \boldsymbol{x} \in D
$$

を満たす．ここに $\chi$ は物体ポテンシャル密度とよばれる ベクトル值関数である。

以下の記述においては，ほとんど自明であるのでアー ギュメントは省略して表記することにする。

\section{3. 積分方程式法による弾塑性問題の解析}

式 (6) は, 弾塑性変位増分場が物体力 $-\left(\boldsymbol{C}: \boldsymbol{d} \boldsymbol{\epsilon}^{p}\right) \cdot \boldsymbol{\nabla}$ を伴った弾性変位 (増分) 場とみなし得ることを示して

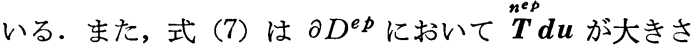


$\left(\boldsymbol{C}: \boldsymbol{d} \epsilon^{p+}\right) \cdot \boldsymbol{n}^{e p}$ の不連続を有することを示している.そ れゆえ, 式 (10), (12) を考慮して, 変位増分 $\boldsymbol{d u}$ を,

$$
\begin{aligned}
\boldsymbol{d u}=\int_{\partial D} \boldsymbol{\Gamma} \cdot \boldsymbol{d} \varphi d S & +\int_{D^{p}} \boldsymbol{\Gamma} \cdot \boldsymbol{d} \boldsymbol{\phi} d V \\
& +\int_{\partial D e p} \boldsymbol{\Gamma} \cdot \boldsymbol{d} \varphi^{e p} d S
\end{aligned}
$$

と仮定してよい，式 (6)，(7)，(10)，(12）より，

$$
\begin{aligned}
& d \varphi+\left(C: d \epsilon^{p}\right) \cdot \nabla=0 \\
& d \varphi^{e p}-\left(C: d \epsilon^{p}\right) \cdot n^{e p}=0 .
\end{aligned}
$$

を得る. 式（13）へ，式 (14)，(15) を代入して Gauß の定理を用いれば，

$$
\begin{aligned}
\boldsymbol{d u}= & \int_{\partial D} \boldsymbol{\Gamma} \cdot\left(\boldsymbol{d} \boldsymbol{\varphi} \mp\left(\boldsymbol{C}: \boldsymbol{d} \boldsymbol{\epsilon}^{p}\right) \cdot \boldsymbol{n}\right) d S \\
& +\int_{D^{p}} \boldsymbol{\Gamma} \overleftarrow{\boldsymbol{\nabla}}:\left(\boldsymbol{C}: \boldsymbol{d} \epsilon^{p}\right) d V \cdots \cdots
\end{aligned}
$$

となる.ここ（および以下）で複号は上が内部，下が外 部問題に対応する. $\boldsymbol{n}$ は $\partial D$ に立てた外向き単位法線べ クトルである.いま，

$$
d \phi=d \varphi \mp\left(C: d \epsilon^{p}\right) \cdot n
$$

とおくと，

$$
\boldsymbol{d u}=\int_{\partial D} \boldsymbol{\Gamma} \cdot \boldsymbol{d} \boldsymbol{\phi} d S+\int_{D^{p}} \boldsymbol{\Gamma}^{\overleftarrow{\boldsymbol{V}}}:\left(\boldsymbol{C}: \boldsymbol{d} \epsilon^{p}\right) d V
$$

を得る.これを時間で積分すれば，

$$
\boldsymbol{u}=\boldsymbol{u}_{0}+\int_{\partial D} \boldsymbol{\Gamma} \cdot \boldsymbol{\phi} d S+\int_{\hat{D}^{p}} \boldsymbol{\Gamma} \overleftarrow{\boldsymbol{V}}:\left(\boldsymbol{C}: \boldsymbol{d} \boldsymbol{\epsilon}^{p}\right) d V
$$

を得る.ここに $\boldsymbol{u}_{0}$ は初期変位であり， $\hat{D}^{p}$ は全過程に おいて降伏の生じた部分の和集合である.

式（17）から計算される境界条件および流れ則を連立 すれば, $\boldsymbol{d} \phi, \boldsymbol{d} \boldsymbol{\epsilon}^{p}$ を未知数として弾塑性解析を行うこ とができる.しかし流れ則の特性を生かすことによっ て, より数值解析に適した積分表示式を得ることができ る. 実際,

$$
d \Psi=\boldsymbol{D}: \boldsymbol{d} \boldsymbol{\epsilon}
$$

とおくと（式 (4)，(5) 参照)，式 (17) は,

$$
\boldsymbol{d} \boldsymbol{u}=\int_{\partial D} \boldsymbol{\Gamma} \cdot \boldsymbol{d} \boldsymbol{\phi} d S+\int_{D^{p}} \boldsymbol{\Gamma} \overleftarrow{\boldsymbol{V}}:\left(\boldsymbol{C}: \frac{\partial f}{\partial \boldsymbol{\tau}}\right) d \Psi d V
$$

と書き直される. $d \Psi$ はスカラーであることに注意すべ きである.

以上の上らにして得られた式 (19) が一重層ポテンシ ヤル法による弾塑性解析の基礎式である. 式 (19) を用 いて境界条件を表示し, 流れ則 (18) と連立して解けば, 弾塑性変位増分場を求めることができる.

次に以上の結果の変形として, 複数降伏条件, および クラックの問題に対する結果を記す.

（i）複数降伏条件の場合,

$$
\boldsymbol{d u}=\int_{\partial D} \boldsymbol{\Gamma} \cdot \boldsymbol{d} \boldsymbol{\phi} d S+\sum_{\substack{i=1 \\\left(f^{i=0}=0\right)}}^{N} \boldsymbol{\Gamma} \overleftarrow{\boldsymbol{V}}:\left(\boldsymbol{C}: \frac{\partial f^{i}}{\partial \boldsymbol{\tau}}\right) d \Psi^{i} d V
$$

$$
d \Psi^{i}=D^{i}: d \epsilon \quad 1 \leqslant i \leqslant N \text { s.t. } f^{i}\left(\tau, \boldsymbol{\xi}^{i}\right)=0
$$

のように拡張できる.

（ii）クラックの場合,二重層ポテンシャルを用いて， $\boldsymbol{d u}=\boldsymbol{d} \boldsymbol{u}_{0}+\int_{S} \boldsymbol{\Gamma}_{\boldsymbol{I}} \cdot \boldsymbol{d} \overline{\boldsymbol{\phi}} d S+\int_{D^{p}} \boldsymbol{\Gamma} \overline{\boldsymbol{V}}:\left(\boldsymbol{C}: \frac{\partial f}{\partial \tau}\right) d \Psi d V$

および式（18）の連立となる（ただし，式（18）のde の項に $\frac{1}{2}\left(\boldsymbol{\nabla} \boldsymbol{d} u_{0}+\boldsymbol{d} u_{0} \boldsymbol{V}\right)$ の項が加わる). ここに $S$ は クラック面, $d u_{0}$ は $\boldsymbol{A}^{*} d \boldsymbol{u}_{0}=0$ を満たす変位增分場で ある. 式（22）は式（17）を得たのとほぼ同じ方法で得 られるが, Swedlow-Cruse の式1 において極限移行を行 っても得られる.なお式 (11) より $\boldsymbol{d} \overline{\boldsymbol{\phi}}$ はクラックの開 口変位增分の 2 倍を意味することになる.

最後に 2 つ注意を付け加える.

(a) 式 (17) は $d \epsilon=d \epsilon^{e}+d \epsilon^{p}, d \tau=C: d \epsilon^{e}, d \tau \cdot \nabla$ $=0$ のみから得られる. したがって, 加速度項が無視で きる籁囲では粘塑性理論にも適用できる. その場合, $d \epsilon^{p}$ は $\tau, \boldsymbol{\varepsilon}$ のみで定まることが多く,未知関数は $d \phi$ のみとなる.

(b) 式 (17)，(18) から得られる積分方程式を陽に書 き下寸ためには, $\boldsymbol{\nabla} \boldsymbol{d u}$ の $D^{p}$ での值および $\partial D$ への極 限形を求めればよい。たとえば 3 次元問題の場合, $D^{p}$ においては,

$$
\begin{aligned}
\nabla d u= & Y:\left(C: d \epsilon^{p}\right)+\int_{\partial D} \nabla \Gamma \cdot d \phi d S \\
& +\int_{D^{p}} \nabla \Gamma^{\overleftarrow{\nabla}}:\left(C: d \epsilon^{p}\right) d V \cdots \cdots
\end{aligned}
$$

となる.ここに $\boldsymbol{Y}$ は，任意の 2 階のテンソル $\epsilon$ に対し $\tau$,

$$
\boldsymbol{Y}: \boldsymbol{\epsilon}=\frac{1}{15 \mu}\left(\frac{3 \lambda+8 \mu}{\lambda+2 \mu} \boldsymbol{\epsilon}-\frac{\lambda+\mu}{\lambda+2 \mu} \mathbf{1} \operatorname{tr} \boldsymbol{\epsilon}\right)
$$

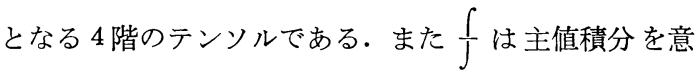
味する. 式 (23) の $\partial D$ 一の極限形は,

$$
\begin{aligned}
& \boldsymbol{\nabla} d u= \pm \stackrel{\boldsymbol{n}}{\boldsymbol{S}} \cdot\left(d \boldsymbol{d} \pm\left(\boldsymbol{C}: \boldsymbol{d} \epsilon^{p}\right) \cdot \boldsymbol{n}\right)+\frac{1}{2} \boldsymbol{Y}:\left(\boldsymbol{C}: \boldsymbol{d \epsilon ^ { p }}\right) \\
& +\int_{\partial D} \nabla \Gamma \cdot d \phi d S+\int_{D^{p}} \nabla \Gamma \overleftarrow{\nabla}:\left(C: d \epsilon^{p}\right) d V
\end{aligned}
$$

と書ける.ここに $\stackrel{\boldsymbol{n}}{\boldsymbol{S}}$ は $\partial D$ の外向き単位法線ベクトル $n$ を用いて，任意のベクトル $\boldsymbol{\phi}$ に対して,

$$
\stackrel{\boldsymbol{n}}{\boldsymbol{S}} \cdot \boldsymbol{\phi}=\frac{1}{2 \mu}\left(\boldsymbol{n} \otimes \boldsymbol{\phi}-\frac{\lambda+\mu}{\lambda+2 \mu}(\boldsymbol{n} \cdot \boldsymbol{\phi}) \boldsymbol{n} \otimes \boldsymbol{n}\right) \cdots
$$

となる 3 階のテンソルである. $D^{p}$ での主值積分は, $\partial D$ 
上に中心を有する半径 $\epsilon$ の半球を $D^{p}$ から除いて積分 を行い， $\epsilon \downarrow 0$ としたときの極限である.

たとえば応力境界值問題では, 式 (25) から計算され る表面力増分に対する境界条件と, 式 (23)，(25）から 計算される流れ則を連立して解くことになるが, 得られ る方程式の可解性を一般的に議論することは容易ではな い.しかし d $\boldsymbol{d}^{\not}$ が与えられた場合, Fredholm の諸定 理”により容易に, 内部問題については与えられた表面 力増分 $\boldsymbol{d} \boldsymbol{f}$ が, 合力 $=0$, 合モーメント $=0$ の条件を満 たすとき，また外部問題では常に解けることを示すこと ができる、いいかえれば，物理的に適切な条件のもと で, $D^{p}$ で滑らかな, 任意の $\boldsymbol{d} \boldsymbol{\epsilon}^{p}$ を有する弾塑性変位增 分場は, 一重層によるポテンシャル表示式 (17) をもつ ことになる。

\section{4. 数值計算法}

本節では, 本論文で採用した数值計算法について述べ る. 3. で述べた一重層ポテンシャル法による一般の応 力境界值問題の解法を例にとる.

数值計算法は, 弾性の場合と基本的には変わらない. すなわち, 未知関数 $\boldsymbol{d} \phi, d \Psi$ を適当な形状関数を用い て離散化し, 選点法によって離散化された $\boldsymbol{d} \boldsymbol{\phi}, d \Psi$ に 関する連立方程式を得, これを解いて近似解を構成す る. また, 増分計算の方法も, FEM などで用いられて いるものと本質的に変わらない。個々の問題点につい て，本論文で用いた解決策を以下に述べる.

(1) 積分の評価法

$\partial D, D^{p}$ を有限個の要素に分割してモデル化し, 各要 素上で未知関数を一定とする. その場合, 計算すべき積 分は解析的に評価したものを用いる. 特異積分を扱う場 合, 常に微積分の順序交換の不可能性が問題となるが, ここでの方法によれば直接微分操作によって式 (23), （25）の上うな形を意識することなく，境界条件や流れ 則を構成することができる.

(2) 塑性域の評価法

$D^{p}$ はあらかじめ降伏の予想される部分を要素分けし ておき, 各要素罒心にとった代表点での応力が $f(\boldsymbol{\tau}, \boldsymbol{\xi})$ $=0$ を満たした時点から除荷が生ずるまで, その要素が $D^{p}$ を構成するものと考える. なお $D^{p}$ のモデル化は， 物理的, 工学的判断によって行わねばならない.

(3) 境界条件における $d \epsilon^{p}$ の処理法

$\partial D$ に接する物体要素では, 代表点を $\partial D$ にとってお けば境界条件に現れる $d \epsilon^{p}$ の処理が容易である.

(4) 増分計算法

いわゆる単純増分法を用いる. 増分幅は物体要素を 1 個ずつ降伏させるように決定する．また，すべての降伏
した物体要素で計算された $d \Psi$ が非負であることを確か め, 負のものがある場合にはその要素が除荷したものと みなして増分計算をやり直す. 連立方程式を解いた直後 に除荷判定ができるのも本手法の利点の 1 つである.

(5) 連立方程式の解法

各ステップの解の精度をそろえるためには直接法を用 いるのがよいと考えられる.ここで Crout 法を用いてい る.

なお,クラックの問題については 5.（3）をみていた だきたい。

\section{5. 数值解析例}

本節ではいままでに述べた手法の 2 次元問題への適用 例を示す.

\section{(1) 円孔の押拡}

円孔の押拡問題 (Fig. 1) は, 平面ひずみ状態, Tresca の降伏条件, 非硬化の仮定のもとに, 部分的に解析的に 解くことができ ${ }^{8)}$, 工学的に重要な応力に対する解析解 が知られている. それゆえ数値解析精度の検証に適した 問題の 1 つである.ここでは無限完全弾性体中の円孔の 押挔問題を解析する.

数値解析に用いた条件は次のようである. $E=2.1 \times$

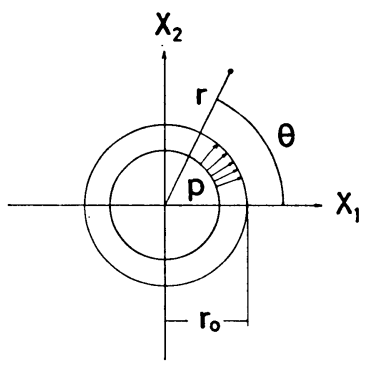

Fig. 1 Circular hole subject to internal pressure.

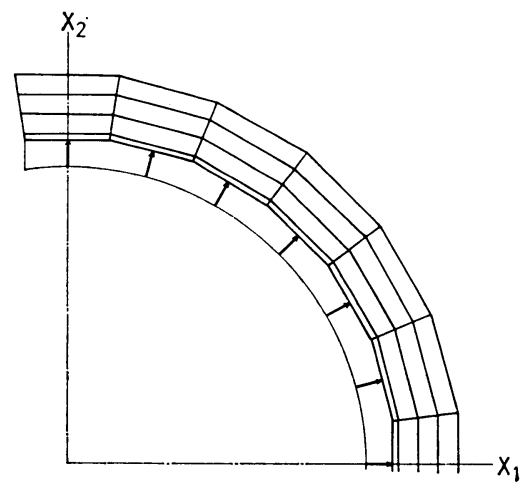

Fig. 2 Model of circular hole. 
$10^{6} \mathrm{~kg} / \mathrm{cm}^{2}, \nu=0.3, \sigma_{y}=2500 \mathrm{~kg} / \mathrm{cm}^{2}$. 降伏条件は von Mises として硬化は考えない（なお Tresca の条件を用 いた解析解で $\sigma_{y}$ を $2 \sigma_{y} / \sqrt{3}$ で置き換えれば von Mi ses の条件による解析の近似解となることが知られてい $\left.\Xi^{8)}\right)$. もち万ん平面ひずみを仮定した。内圧 $p$ は 1500 , $1650,2000 \mathrm{~kg} / \mathrm{cm}^{2}\left(0.6,0.66,0.8 \sigma_{y}\right)$ の 3 ケースと した. 数值計算に用いたモデルを Fig. 2 に示す. 原点 対称問題として解析したので，表面要素 12 ，物体要素 48 を使用したことになる．また寸法は最も外側にある 頂点が半径 $1.070,1.070,1.200 r_{0}$ の円周上に乗るよう に決定した．なお解析解から求まる各ケースの塑性域半 径は，各ケースそれぞれ 1.020, 1.074, $1.213 r_{0}$ である.

次に解析結果を示す. Fig. 3 には周応力 $\tau_{\theta \theta}$ の解析 結果を示した. 実線は解析解に上記の修正を加えたもの である. 各ケースともかなり良好な結果である．誤差は 最大のもので約 $4 \%$ である. Fig .4 は $\tau_{r r}$ の解析結 果である. 図の $\nabla$ は弾塑性境界を表している。これも かなり良好な結果であり，誤差は最大のもので約 $5 \%$ で

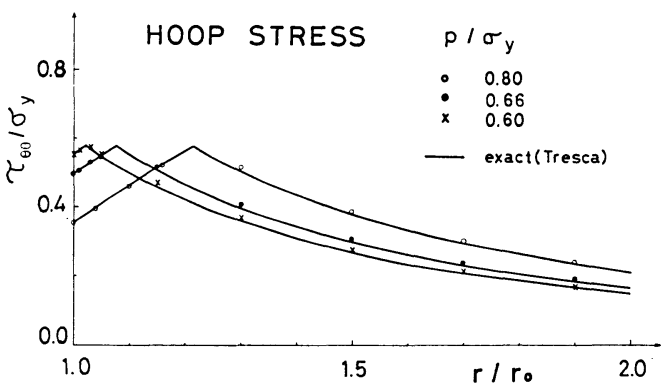

Fig. 3 Hoop stress around a circular hole subject to internal pressure.

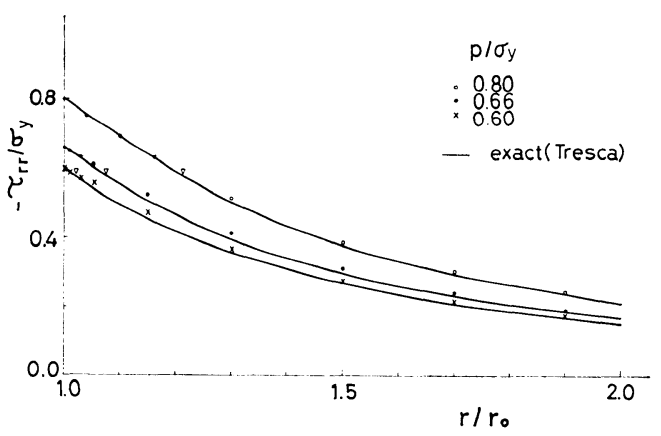

Fig. $4 \tau_{r r}$ around a circular hole subject to internal pressure.

Table $1 \quad \tau^{\prime}: \tau^{\prime} / \frac{2}{3} \sigma_{y}{ }^{2}$ in the plastic zone; circular hole subject to internal pressure, $p=0.8 \sigma_{y}$.

\begin{tabular}{c|c|c|c|c}
\hline$r / r_{0}$ & 1 (Boundary) & 1.041 & 1.101 & 1.160 \\
\hline$\tau^{\prime}: \tau^{\prime} / \frac{2}{3} \sigma_{y}{ }^{2}$ & 1.0006 & 1.0008 & 1.0006 & 1.0006 \\
\hline
\end{tabular}

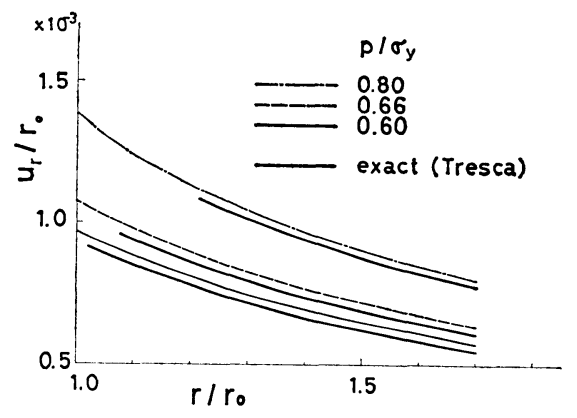

Fig. 5 Displacement around a circular hole subject to internal pressure.

ある.なお，これらの図から一般に弾性域の応力を精度 よく求めることが, 塑性域の応力の評価より困難である ことがわかる. Table 1 は $p=0.8 \sigma_{y}$ の場合の塑性域 での降伏条件の満足度を示している. もちろん正解では $\tau^{\prime}: \tau^{\prime} / \frac{2}{3} \sigma_{y}{ }^{2}=1$ となる ( $\tau^{\prime}:$ 偏差応力).これより単純 増分計算によっても累積誤差はあまり問題にならないこ とがわかる.もっとも，この数字自体は，応力増分が正 確に求まっておれば単純増分計算でも達成し得る程度の 值であることを示すことができるので，特に警くべきも のではない：むしろ応力が正確に求まっていることの証 明と考えてよいであろう（なお $d \epsilon^{p}=\tau^{\prime}\left(\tau^{\prime}: d \epsilon\right) / \frac{2}{3} \sigma_{y}{ }^{2}$ という表示式は自己修正特性，すなわち誤差によって $f(\tau) \neq 0$ となった場合， $f(\tau)$ を 0 にもどす方向を向く 特性を有していることを示すことができる).

最後に変形に関する計算結果を Fig. 5 に示す. 太線 は解析解 (弾性域での結果のみ知られている) である. これをみると結果はやや過大（誤差 $6 \%$ 程度）である。 一重層ポテンシャル法を用いた場合, この程度の粗いメ ッシュでは変位の精度がこの程度となること, およびメ ッシュの細分によって精度を向上させ得ることは，弾性 問題の解析における実績に照らして予想し得るものであ る.

以上のように，かなり分割が粗いにもかかわらず，十 分良好な結果が得られたといえよう。

\section{（2）円孔を有する板の二軸引張}

Tresca または von Mises の降伏条件に従う，円孔を 有する無限非圧縮完全弾塑性体が無限遠方で二軸的に引 張を受ける場合 (Fig. 6) の解析解は, Галин (Galin) によって求められている9). 本節ではこの問題について の解析解と数值結果を比較する.

数值解析に用いた材料特性は, Poisson 比以外は $\mathbf{5}$. （1）におけるものと同一である. Poisson 比は非圧縮性 を近似的に満たし，かつ数值精度を損なわないために 
0.45 とした. 応力状態は, 無限遠で $\tau_{11}{ }^{0}=1750 \mathrm{~kg} / \mathrm{cm}^{2}$ $\left(0.70 \sigma_{y}\right), \tau_{22}{ }^{0}=1875 \mathrm{~kg} / \mathrm{cm}^{2}\left(0.75 \sigma_{y}\right)$ の場合, およ び $\tau_{11}{ }^{0}=1875 \mathrm{~kg} / \mathrm{cm}^{2}\left(0.75 \sigma_{y}\right), \tau_{22}{ }^{0}=2125 \mathrm{~kg} / \mathrm{cm}^{2}(0.85$ $\left.\sigma_{y}\right)$ の 2 ケースとした. 応力径路は一様な初期応力 $\tau^{0}$ を与え, 境界での表面力を $\tau^{0} \cdot n \rightarrow 0$ とするように選ん だ. 数值計算用のモデルとしてはケース 1 の場合 5. (1) の $p=0.8 \sigma_{y}$ の解析に用いたもの, ケース 2 の場合に はFig. 7 に示したものを用いた.

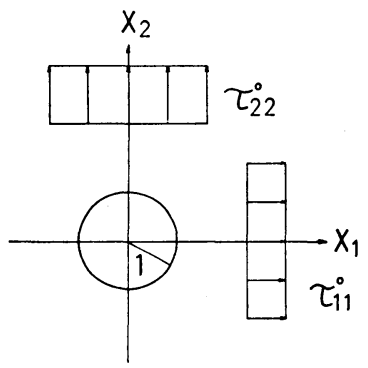

Fig. 6 Circular hole subject to biaxial tension.

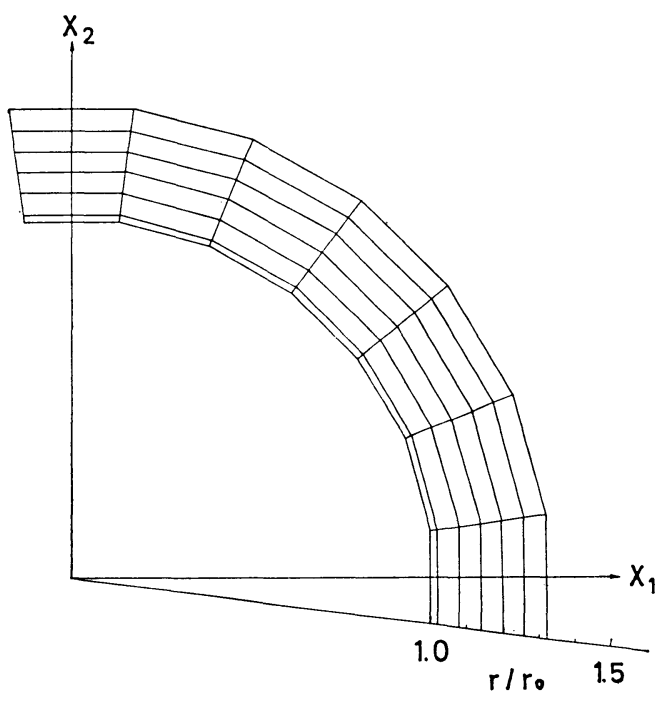

Fig. 7 Model of circular hole for Galin's problem.

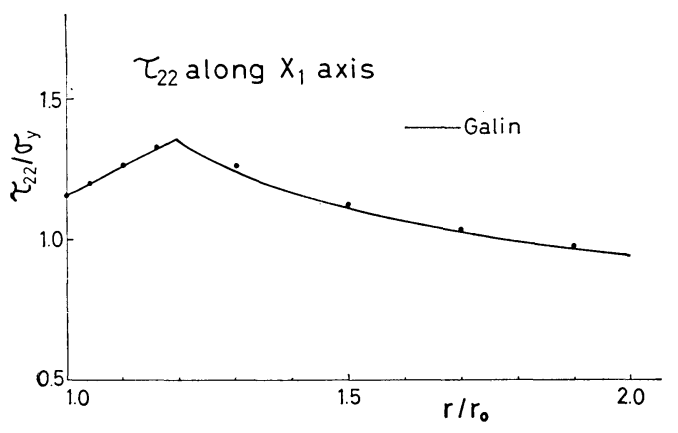

(a)
次に解析結果を示す. Fig. 8 (a), (b) は各ケースの 塑性域を示している.太線は解析解（棈円）を示し，斜

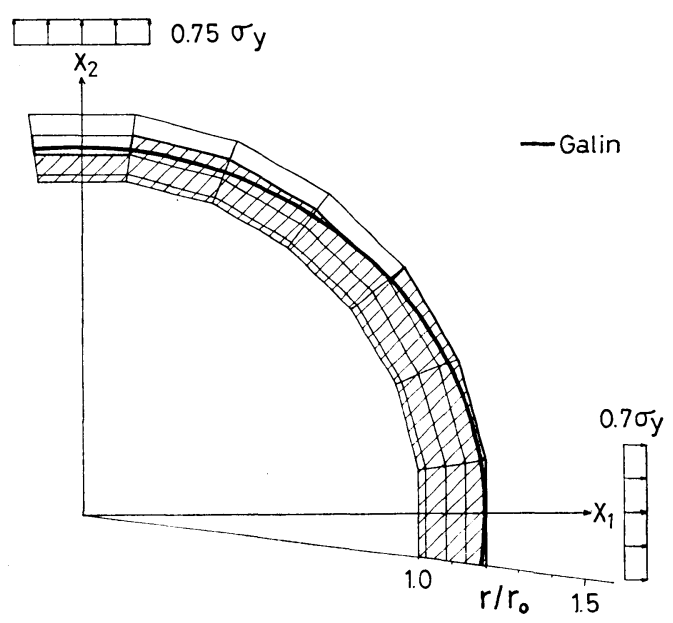

(a)

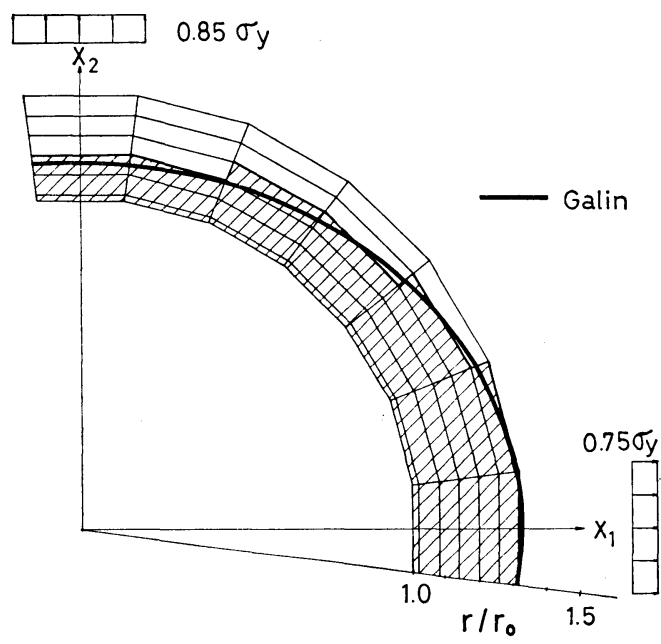

(b)

Fig. 8 Plastic zone around a circular hole subject to biaxial tension.

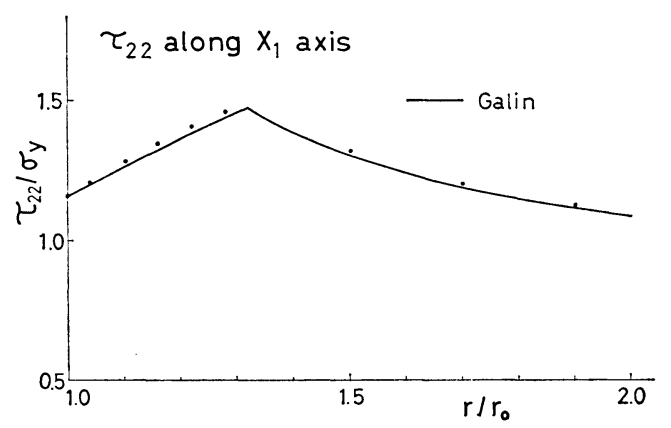

(b)

Fig. $9 \tau_{22}$ along $x_{1}$ axis; circular hole subject to biaxial tension. 


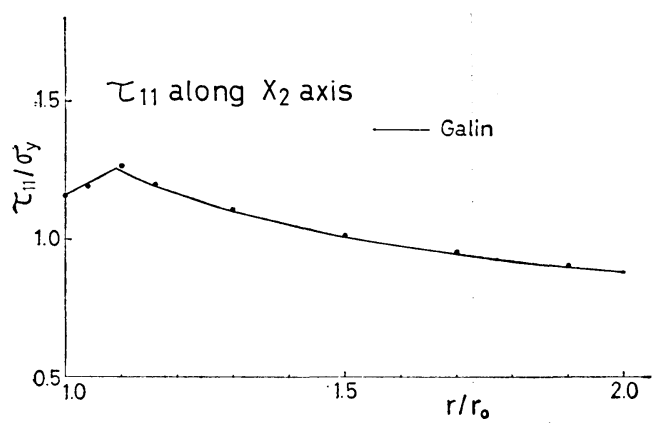

(a)

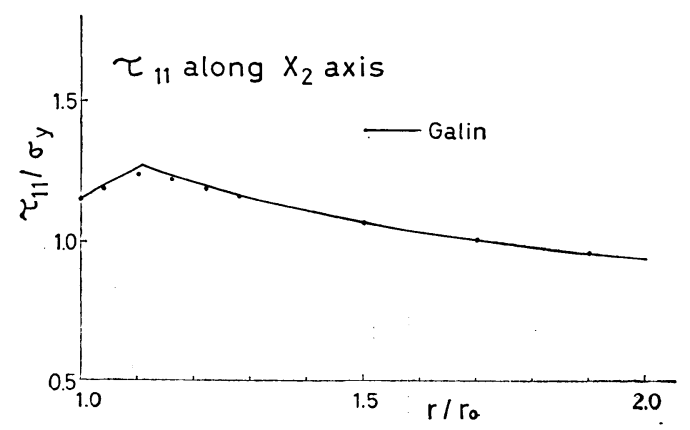

(b)

Fig. $10 \tau_{11}$ along $x_{2}$ axis; circular hole subject to biaxial tension.

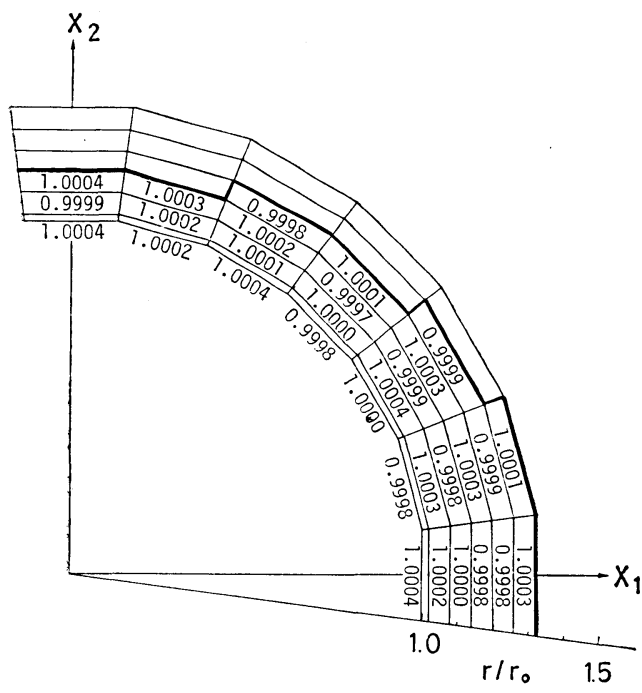

Fig. $11 \tau^{\prime}: \tau^{\prime} / \frac{2}{3} \sigma_{y}{ }^{2}$ in the plastic zone; circular hole subject to biaxial tension.

線は数值結果を示している. 両者はかなりよく一致して いる. Fig. 9 (a), (b) は各ケースの $x_{1}$ 軸に沿う $\tau_{22}$ の分布を示している.おのおの $2,1 \%$ 程度の誤差であ る. Fig. 10 (a)，(b) は各ケースの $x_{2}$ 軸に沿う $\tau_{11}$ の 分布である.これも弾塑性境界が正解とモデルとでは多

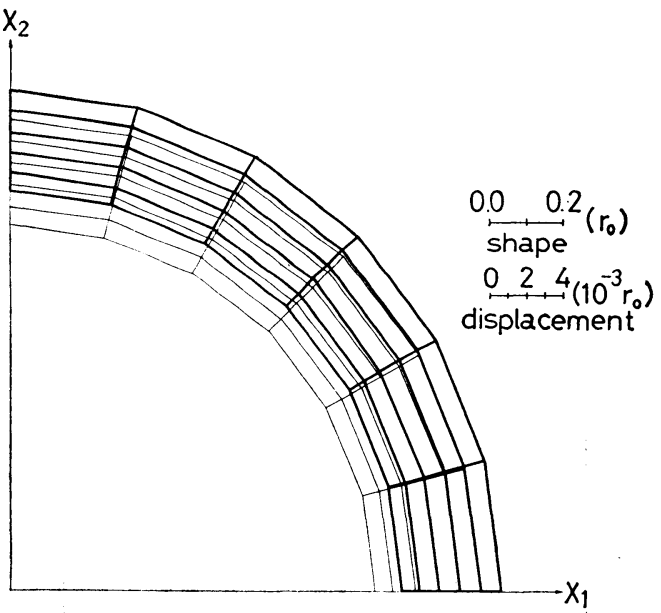

Fig. 12 Deformation around a circular hole subject to biaxial tension.

少ずれているにもかかわらず良好な結果である，Fig. 11 は, ケース 2 の $\tau^{\prime}: \tau^{\prime} / \frac{2}{3} \sigma_{y^{2}}$ を表す. 数值的な誤 差の影響, および上述の $\boldsymbol{d} \boldsymbol{\epsilon}^{p}$ の自己修正特性のために $\tau^{\prime}: \tau^{\prime} /\left(\frac{2}{3} \sigma_{y}\right)^{2}<1$ のところむあるが, 全体的に $\tau^{\prime}$ : $\tau^{\prime} / \frac{2}{3} \sigma_{y}{ }^{2} \simeq 1$ が十分良好な精度で達成されており, 累積 誤差が小さいといえよう. 最後に Fig. 12 にケース 2 について計算された円孔周辺の変形を示す（解析解は弾 性域におけるもののみ知られている).

\section{（3） クラックの弾塑性解析}

クラック先端近傍の弾塑性解析は, 近年盛んな非線形 破壊力学の基礎データともなるもので, 重要である. そ の数值解析法としては FEM が広く用いられているが， 特殊な要素を用いるなどの工夫が行われることが多い. 一方, 二重層ポテンシャルは, 特異性が高いために一重 層ポテンシャルより多少使いにくい点があるが, その物 理的実体が変位の不連続であるため, 使い方にさえ注意 すれば自然なクラック解析手法となると考えられる。 な お, いわゆる体積力法 ${ }^{10)}$ は, Poisson 比=0 とした場合 に二重層ポテンシャルがダブレットを積分したものにな ることを利用したものと考えてよい.

さて, 弾塑性解析を行う前に次の点に注意する.すな わち，被圧クラック（Pressurized Crack）に関する弾性 問題の場合, 二重層・Galerkin 法は選んだ 近似関数空 間, すなわち選んだ形状関数 $\boldsymbol{\psi}^{\mathrm{I}}(1 \leq I \leq N)$ に対して,

$$
\boldsymbol{W}^{\mathrm{I}}=\int \boldsymbol{\Gamma}_{\mathrm{I}} \cdot \boldsymbol{\phi}^{\mathrm{I}} d S \quad 1 \leq I \leq N
$$

で張られる $N$ 次元線形空間におけるポテンシャルミニ マム原理に等価である.これは式（11）および $\Delta^{*} W^{\mathbf{I}}=$ 0 から明らかである.そこで, 区分線形近似（二重層密 


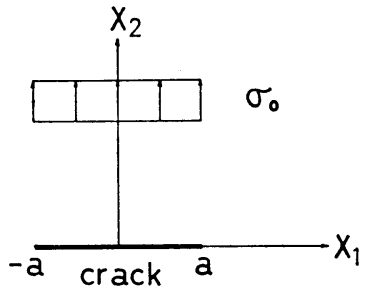

Fig. 13 Central crack subject to mode I tension.

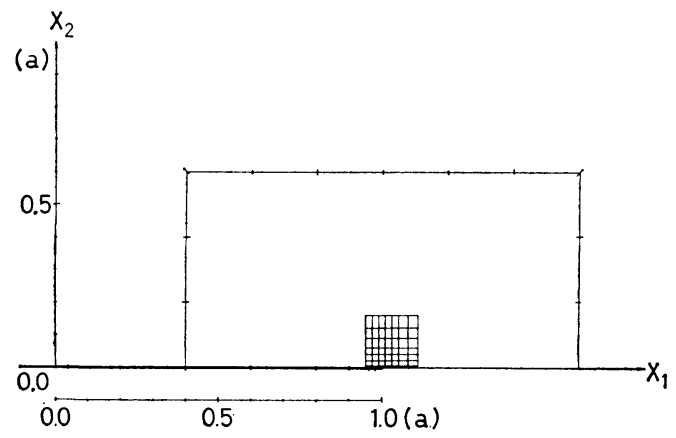

Fig. 14 Model of central crack.

度は, 一重層密度より高次の近似をすべきであることが わかっている(4). 二重層・Galerkin 法を用いて，無限 板中のモードI の荷重を受ける中央クラック（Fig. 13） の問題を弾性解析した. モデルは Fig. 14 のクラック の部分である ( 8 自由度). その結果, 平面ひずみ, $E=$ $2.1 \times 10^{6} \mathrm{~kg} / \mathrm{cm}^{2}, \nu=0.3$, 半クラック長 $5 \mathrm{~cm}$ の条件下 で, $\tau_{22}{ }^{0}=\sigma_{0}=1000 \mathrm{~kg} / \mathrm{cm}^{2}$ の場合, ひずみエネルギー 密度 $W$, 表面力 $\boldsymbol{t}$, 変位 $\boldsymbol{u}$ で次のように定義される $J$ 積分,

$$
J=\int_{C} W d x_{2}-\int_{C} \boldsymbol{t} \cdot \frac{\partial \boldsymbol{u}}{\partial x_{1}} d s
$$

は, $6.811 \mathrm{~kg} / \mathrm{cm}$ と求まった. 正解 6.807 と比較して誤 差は $0.06 \%$ である. 以上のようにして二重層・Galerkin 法は, 非常に有効なクラックの弾性解析法であるこ とがわかる。

次に弾塑性解析に上の手法を応用する. すなわち, 境 界条件に Galerkin 法を用いる.ただし流れ則に関して は, 簡単のために選点法を用いる. なお, この場合, 弾 性のときと違ってクラックチップでの二重層密度 $d \boldsymbol{\varphi}$ は 0 でない. 本来この点を考慮すべきであるが，ここでは 簡単のためにこれを無視し，小規模降伏の場合のみを解 析する.

材料特性は, $H^{\prime}=d \bar{\sigma} / d \bar{\epsilon}^{p}=0.05 E$ の等方硬化を仮定 した以外は 5. (1) と同一である.クラックとしては Fig. 13 の半クラック長 $5 \mathrm{~cm}$ の中央クラックを選び, 応力条件は無限遠での モード I の引張応力 $\sigma^{0}=600$, $800,1000 \mathrm{~kg} / \mathrm{cm}^{2}\left(0.24,0.32,0.40 \sigma_{y}\right)$ の 3 ケースと した. 応力径路は $\tau_{22}{ }^{0}=\sigma_{0}$ を初期応力として与えるもの

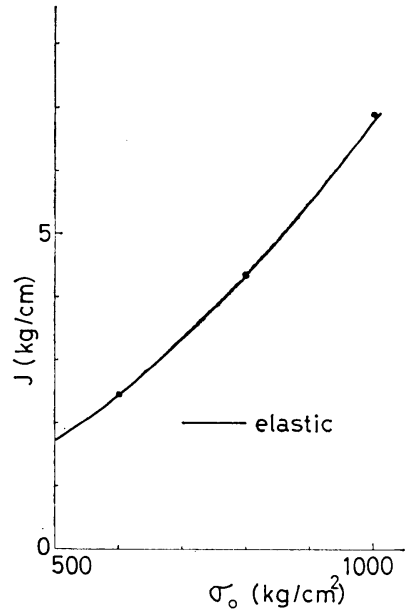

Fig. $15 J$ integral for central crack subject to mode I tension.

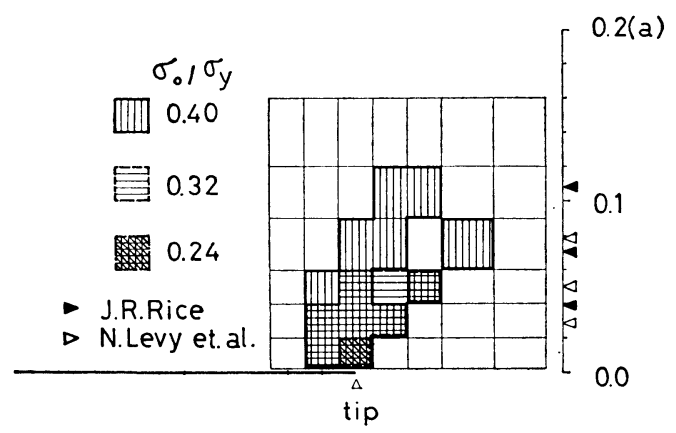

Fig. 16 Plastic zone near the crack tip.

と, 無限遠の応力が 0 から $\sigma^{0}$ まで漸増するものの $2 つ$ を解析したが，結果に大差がなかったので以下では前者 の結果を述べる.なお, 解析に用いたモデルは Fig. 14 に示すものであって, 図の外側のループを用いて $J$ 積 分を評価した。

Fig. 15 は $J$ 積分の計算結果である. 実線は弾性の ものである.これより小規模降伏の条件は十分に満足さ れていることがわかる. Fig. 16 は塑性域形状の解析結 果である. 最大塑性域寸法については J. Rice が $J$ 積 分および剛塑性理論を用いた近似式を得ている ${ }^{11)}$.また N. Levy らは FEM を用いて小規模降伏のときの最大 塑性域寸法評価式を得ている ${ }^{12)}$. Fig. 16 中にそれらか ら予測される結果をあわせて記入してある.これらを比 較するとほぼ数值結果は妥当なものといえよう。ただし Fig. 16 で $\sigma^{0}=1000 \mathrm{~kg} / \mathrm{cm}^{2}\left(0.4 \sigma_{y}\right)$ の場合, 塑性域 に「穴」が生ずるのは物理現象かどうかは不明である。 計算上は, これらの要素は降伏後除荷するという結果に なる.

このように, クラックの解析については円孔の問題に 比較してやや不十分である.この点については前述のク 
ラックチップでの二重層密度の問題や, 体積積分の項に おける $\boldsymbol{d} \boldsymbol{\epsilon}^{p}$ のクラックチップでの処理（特異性）など についての研究が今後必要であろう.

最後に，計算時間について述べる．たとえば本論文の 5. (2) で述べた円孔板の二軸引張のケース 2 の場合, 31 ステップの増分計算に 16 秒の CPU time を要した (京 都大学大型計算機センターの M 190 使用). これより, 十分高速なアルゴリズムであると結論できる. ただし演 算時間は使用する積分計算用のルーチンの効率に大きく 左右され得ることを指摘する.

\section{6. 結 論}

一重層ポテンシャル法による弾塑性解析法が定式化さ れ, その変形として二重層ポテンシャル法によるクラッ クの弾塑性解析法が定式化された. これらは, 従来の弾 塑性解析法に比べて積分計算量が少なく, 十分実用的な ものであることが特色である.

数値解析例として円孔の押挔, 円孔を有する板の二軸 引張, クラックの弾塑性解析を行った. 前二者では, 十 分高精度の解析が高速度で行われることがわかった.

なお, 本論文で示された手法は, 2 次元解析だけでな く, 3 次元解析にもそのまま使用できる. 特に, 各物体 要素の未知数が 1 個という性質は 3 次元の場合にも保存 され，実用的な 3 次元解析手法となることが予想され る.それゆえ，今後この方面への適用が期待できよう。

\section{参 考 文 献}

1) Swedlow, J.L. and T.A. Cruse : Formulation of Boundary Integral Equations for Three-Dimensional Elasto-Plastic Flow, Int. J. Solids Structures, Vol. 7, pp. 1673 1683, 1971.

2) Rzasnicki, W. and A. Mendelson : Application of Boundary Integral Method to Elastoplastic Analysis of V-notched Beams, Int. J. Fracture, Vol. 11, No. 2, pp. 329 342, 1975.

3）この方面の review として,

Mendelson, A.: Boundary-Integral Methods in Elasticity and Plasticity, NASA, TN D-7418, 1973.

Mendelson, A. and L.U. Albers : Application of Boundary Integral Equations to Elastoplastic Problems, Boundary-Integral Equation Method; Computational Applications in Applied Mechanics (Ed. by T.A. Cruse \& F.J. Rizzo), Proc. ASME; AMD-Vol. 11, 1975.

などがある.

4）小林昭一・西村直志 : 積分方程式法の解析精度の向上に 関する考察, 土木学会論文報告集, No. 291, pp. 15～26, 1979.

5) Mukherjee, S. : Corrected Boundary-Integral Equations in planer Thermoelastoplasticity, Int. J. Solids Structures, Vol. 13, pp. 331 335, 1977.

6) Bui, H.D. : Some Remarks about the Formulation of Three-Dimensional Thermoelastoplastic Problems by Integral Equations, Int. J. Solids Structures, Vol. 14, pp. 935 939, 1978.

7) Kupradze, V.D. : Potential Methods in the Theory of Elasticity, (Tr. by H. Gotfreund), Israel program for scientific translations, Jerusalem, 1965.

8） R. ヒル : 塑性学, 培風館, 1954 .

9) Galin, L.A. (Галин, Л.А.) : Plane Elasto-Plastic Problem, Plastic Zones around Circular Openings in Plates and Beams (in Russian), P.M.M., Vol. 10, pp. 367 386, 1946.

Savin, G.N. : Stress Concentration around Holes, (Tr. by E. Gros), Pergamon, 1961.

10) Nishitani, H. and Y. Murakami : Stress Intensity Factors of an Elliptical Crack or a Semi-Elliptical Crack Subject to Tension, Int. J. Fracture, Vol. 10, No. 3, pp. 353 368, 1974.

11) Rice, J.R. : Mathematical Analysis in the Mechanics of Fracture, Chapt. 3 in "FRACTURE" (Ed. by H. Liebowifz), Vol. 2, Academic Pr., 1967.

12) Levy, N., P.V. Marchal, W.J. Ostergren and J.R. Rice : Small Scale Yielding Near a Crack in Plane Strain; A Finite Element Analysis, Int. J. Fracture Mech., Vol. 7, No. 2, pp. 143 156, 1971.

(1979.7.24 - 受付) 